\title{
Trinitarian Anthropology
}

J Theron

(Huguenot College, Wellington)

\section{ABSTRACT}

\section{Trinitarian Anthropology}

This article looks at the problem of the so-called "point of contact" between God and mankind, or more particularly, the relation between trinity and anthropology. Does Christian anthropology develop from the doctrine on creation, the human nature of Christ or the work of the Holy Spirit? In opposition to the current trinitarian perspectives on humanity, which mainly focus on relational similitude, the theology of the Dutch theologian, Oepke Noordmans critically resists any attempt at finding analogies between the trinity and humanity. According to him, creation is judgment of God, which has critical implications for any independent anthropology: There is no perpetuation of the incarnation in our humanity, church or liturgy after the resurrection, and the re-creative work of the Spirit does not have a point of contact with any constitutive element in our humanity. The judgment of the cross reaches from creation across history to recreation.

\section{INTRODUCTION}

Where would one find the point of contact between God and man? This question has troubled human kind for centuries. Michelangelo proposes such a point in his artwork, the "Creation of Adam", as a space between the finger of God and the finger of Adam. How much violence has been done within that little space? One could say that eternal salvation and eternal perdition of all mankind lie within that seemingly innocent gap.

A central concern within Christian theology is where mankind should feature within the doctrine. Theologically the point of contact between God and mankind is usually established by a discussion of Genesis 1:27 saying that mankind was created in the "image of God". This imago Dei has been related to the trinity to some degree in the past, mostly in an attempt to find some kind of analogy between the trinitarian being of God and the nature of mankind. In trying to find the point of contact in Christology, theologians attempt to extend the image of God to Christ as the true imago Dei for humans to imitate. This approach often has the result that we view 
our true humanity as something we can attain by imitating some moral characteristics in the person of Christ. Attempts to find the point of contact within Pneumatology often lead to many and varied forms of reducing the Holy Spirit to the human spirit.

\section{THE TRINITARIAN IMAGE OF GOD}

The Church Fathers already attempted to work out the doctrine of the creation of man in the image of God in relation to the trinity. Augustine set expounded the psychological analogy between God and man in De Trinitate where mind (memory), knowledge and love ${ }^{1}$ reflect the trinity in man. Merriel $(2005: 131,137)$ indicates how Thomas Aquinas builds on this analogy of Augustine, but sees memory as the retention of knowledge and love. "Thus, the indwelling of the Trinity is basically the graced presence of God to the mind's faculties of intellect and will in a way that makes the intellect participate in the divine procession of the Word and the will participate in the divine procession of Love”. Boulgakov (1946:126127) fundamentally criticises this idea of causality in the double procession of Son and Spirit as intellect and will in Western trinitarian thought, by pointing out its speculative character: "L'occident se mit de plus en plus à regarder la Sainte-Trinité comme un système de deux processions, processio intellectus et processio volutatis; ce qui paracheva et stabilisa une certaine conception figée et anthropomorphe de la Sainte-Trinité, ...cette généralisation (DUAE processiones) a-t-elle quelque fondament dans la Parole Divine, dans la Révélation directe?”

There have been renewed attempts in recent years to apply the doctrine of the trinity to Christian anthropology ${ }^{2}$. Smail (2005:183)

1 Mens, notitia et amor in De Trinitate Book 9 chapter 4 (4) (Ipsa igitur mens et amor et notitia eius tria quaedam sunt, et haec tria unum sunt, et cum perfecta sunt aequalia sunt) changed to memory, understanding and will (memoria, intelligentia, voluntas) in Book 10 chapter 11 (18) (Haec igitur tria, memoria, intellegentia, voluntas, quoniam non sunt tres vitae sed una vita, nec tres mentes sed una mens, consequenter utique nec tres substantiae sunt sed una substantia.) (http://phil.flet.mita.keio.ac.jp/person/nakagawa/texts.html\#august)

2 From a pastoral-theological approach one finds a great interest in a trinitarian anthropology, for example, Pastoraat in trinitarisch perspectief by JW van Pelt, Pastoral Couseling, Trinitarian Theology, and Christian Anthropology by SC Guthrie jnr. 
recently attempted to indicate how this image is the reflection of the trinity in our humanity. For him the Imago Dei is the Imago Trinitatis and these characteristics of God must be reflected in human beings: "If the distinguishing characteristic of the Father is sovereign and initiating love and if the distinguishing characteristic of the Son is freely obedient love, then the distinguishing characteristic of the Spirit - hard to capture in a single phrase - is what we might call perfecting creativity”. Smail (2005:107) has an affinity for the Eastern view, which allows the persons within the trinity to be more seperate, which in turn affirms the current relational understanding of personal reality.

His view conforms to post-foundational or post-modern interest in "relationality" and attempts to demonstrate how well the trinitarian model fits into this area of study. Quellet works within this approach and sees an analogy between the family and the trinity in his book Divine Likeness: Towards a Trinitarian Anthropology of the Family. In his book The Social God and the Relational Self, Grenz (2001:xi, 5) indicates the concept of the image of God is shifting from the modern emphasis on rationality to the post-modern concern for relationality: "Rather than placing the methodological weight on a supposed connection between human and divine rationality, extending the insights of trinitarian theology to anthropology sets a focus on relationality". He further points out how this agreement on the centrality of relationality is almost universally accepted and that it joins Catholic, Orthodox and Protestants together as well as liberation, feminist, evangelical, philosophical and process theologians. Dixon (1998:169-170) points out the consensus between natural and social sciences on relationality ${ }^{3}$ and even goes as far as saying that "...science can serve as the foundation for a Christian anthropology provided it is completed by the trinitarian principle...”.

These attempts to view mankind's connection to God from the earlier rational to the present relational way, do not escape the dubious analogical approach. According to Van de Beek (1998:4849) an injustice in done to the qualitative difference between God

3 Gunton (1995:95) also attempts to show the conceptual relatedness between trinitarian theology and modern science. 
and mankind if God's fatherhood is appropirated in an attempt to deduce some argument for the relation between human beings. He extends this to the trinity when he says, "...that the words 'Father' and 'Son' and 'Holy Spirit' are symbols to point out the different aspects of the divine being and not descriptions of individual relations in humans..."”.

The difficulties with this analogical approach ${ }^{5}$ are further illuminated by the Scriptural references to the relationship between the Father and the Son. The problematic nature of finding an analogy between the relationality within the trinity to our human relationality becomes evident. Surely a human father is not prompted to betray his son (as stated of the Father in Rm 8:32) for the salvation of the world, neither are mothers to lead their children into the dessert to be tempted by the Devil (as the Spirit did in Lk 4:1).

A purely relational view of Jesus Christ will explain with great difficulty why his disciples were greatly troubled by many of his words (Mt 19:25; Jn 6:52-71) and why all of them deserted Him when He was doing the will of God. Quellet (2007:348), who draws a relational analogy between the family and the trinity is criticised by Browne for not taking more radical texts into account like Matthew 12:49 where Christ radically relativises family relationships. Furthermore Luke 14:26 states that if you do not hate your family members and yourself, you cannot be a disciple of Christ $^{6}$. The relationality within the trinity, as an analogy of human

4 “...dat de woorden 'Vader' en 'Zoon' en 'Heilige Geest' symbolen zijn om de verschillende aspecten van het goddelijke wezen aan te duiden en niet beschrijvingen van individuele relaties op menselijke manier...” (Van de Beek 1998:48-49)

5 Grenz (2001:296) calls the analogy, which connects God's relationality to human relationality an analogia relationis. He points out that this form of analogy was more acceptable to Barth than the earlier analogia entis.

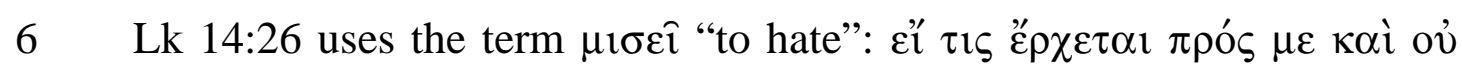

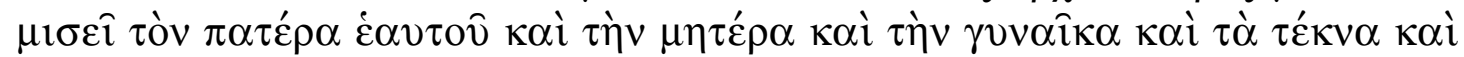

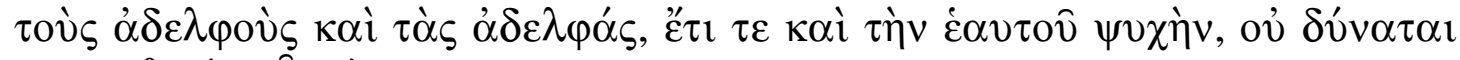

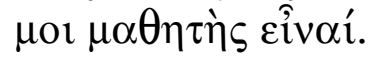


relationality proposed by Smail ${ }^{7}$ and others, becomes incomprehensible with the words "My God, my God why have you forsaken me".

When relationality is given Scriptural content, it becomes quite problematic to hold on to the relational analogy. In taking away the content of both the inter-trinitarian relationships and the problematic relationship between Jesus Christ and the religious leaders, his disciples and family in Scripture, one is left with the empty general statement that mankind exists within different relations.

The Reformation views sin as a broken relationship, which radically impacts on the relational analogy. The Reformation did not see an analogy between the relationality of God and man, but confessed that man can only be understood in his relationship to the triune God. In emphasising relation over against essence, relationality itself is seen as the essence of humanity. In discussing the filioque doctrine, Aldenhoven (1981:132) explains that one cannot equate substance with relations either in the trinity or in humanity without taking away the mystery of either, "Even the insights contributed by personal and relational thinking to our understanding of the human person do not end up in a definition of the person which equates its substance with its relations. On the contrary, in the last analysis even the human person remains a mystery which while revealed in relationships cannot be dissolved by identification with these relationships".

This idea of relationality is well received in an African mould by the concept of ubuntu (umuntu ngumuntu ngabantu) where "a person is a person through others" (Ndungane 1994:196). The alarming consequence of this relational view could just as well present itself in an Apartheid state. If the white Afrikaner is what he/she is through other people (his/her close friends and relatives), what motivation would he/she have had to criticise his/her own people in the Apartheid government? If Christ was a man through other men, then the disciples took away his identity when they deserted him.

7 Smail has a long section on Feuerbach and his atheistic reduction of God to anthropology. In my view his theology would be very prone to attack from Feuerbach's idea of projection. 
In agreement with Grenz one has to acknowledge that the rationalism of modernism reduced humanity to an essential (lonely) self, but post-modern relationality, which he clads in trinitarian language, reduces humanity to ever-changing relations without content. This does not do justice to a Scriptural view of mankind. Not relationality defines humankind, but our relationship to the Father, the Son and the Holy Spirit. Berkouwer (1957:100) emphasises that the relationship between God and mankind must be qualified from Scriptures, which illustrates this relationship as one of grace.

For Noordmans (1979:242) the relationship between God and mankind is not to be understood by way of analogy and comparing of natures, but by way of revelation. He points out that there is no doctrine of mankind in the Apostolic Creed. The doctrine of mankind must be set out in a discussion about God the Father and again in a discussion about Jesus Christ and again with the Holy Spirit ${ }^{8}$. Mankind never features independently ${ }^{9}$, but human kind always features in relation to God from a trinitarian perspective: "...the trinitarian approach dissolves the doctrine on mankind. Mankind features as creature, as lost in sin and as believer; three times in a different manner" ${ }^{10}$. One cannot set out his anthropology without studying his trinitarian theology. Noordmans (1979:177) himself says that anthropology away from the trinitarian doctrine has dogmatic consequences; namely, that the trinity has to take on the form of a doctrine of sin and grace. To understand oneself and humanity one has to take sin into account. Sin more fundamentally determines our being than reason, will and any other attribute

8 Noordmans refers to Calvin's treatment of the doctrine of man in this fashion by referring to the Institutes I, 15; II,1-6 and III 6-10.

$9 \quad$ Too easily in history the divinity of trinity and especially the Spirit has been anthropologically reduced to the detriment of the gospel: "Wanneer men, bij de belijdenis van de Heilige Geest, voor Vader, Zoon en Heilige Geest menselijk verstand, gevoel en wil in die plaats gaat stellen en de godheid des Geestes en het scheppende van zijn werk niet in volle heerlijkheid uitbrengt, dan berooft men de prediking van haar kracht...” (Noordmans 1979:248).

10 "...de trinitarische behandeling doet de leer van de mens in stukken vallen. Hij komt voor als schepsel, als verlorene en als gelovige; driemaal telkens anders" (Noordmans 1979:242). 
(including relationality JT), because it places us directly in relation to God (Noordmans 1980:395).

In staying true to Revelation, Noordmans (1979:172) warns that the dogma of the trinity and the dogma of the two natures of Christ must guard against becoming either a philosophical discussion on the being of God or mere anthropology. If the relationality, which is a central topic in the current debate, is not viewed from the content of Scripture, it has nothing to do with the Christian belief in the Father, the Son and the Holy Spirit. The work of Noordmans provides a Scriptural view on the relation between the trinity and mankind that respects the distinction between the two ${ }^{11}$.

I will consequently look at three pivotal statements of Noordmans with regard to his critical trinitarian view of man, namely: creation as division ${ }^{12}$, incarnation as cross $^{13}$ and the Spirit on all flesh ${ }^{14}$.

\section{CREATION AS DIVISION}

Noordmans (1979:255-256) explicitly places creation within a trinitarian and soteriological perspective in his work Herschepping: "Falling into sin, misery and comfort, fit together well. We know this through the revelation of the Father, Son and Spirit. But a lovely world, noble humanity, a beautiful soul, we cannot use in dogma and preaching” ${ }^{15}$. Creation is not formation ${ }^{16}$, but division ${ }^{17}$. God created

11 Smit (1995:171) in his review of the doctoral thesis by Van der Kooi on Noordmans says that the question Noordmans' work presupposes is: "Waar en hoe raakt de werkelijkheid van God onze menselijke werkelijkheid? Hoe kunnen we het anders zijn ervan eerbiedigen en welke bestaansvorm wekt zij in het leven op?”.

12 In “Verzamelde Werken II”, Noordmans (1979:245, 251, 255, 259, 263) refers to creation in this way.

13 Noordmans does not use these terms in this relation, but the author sums up his criticism of the incarnation in this way.

14 In Verzamelde Werken II, Noordmans (1979:365, 370, 389, 425) speaks thus about the work of the Holy Spirit.

15 ..." Val, ellende, vertroosting, die passen wel bij elkaar. Die kennen wij door de openbaring van Vader, Zoon en Geest. Maar een mooie wereld, een edel mens, een schone ziel, die kunnen wij in de preek en de dogmatiek niet gebruiken...” (Noordmans 1979:255-256). 
heaven and earth and subsequently divided light and darkness, day and night, the waters above and below” (Noordmans 1979:251).

Creation is no neutral entity ${ }^{18}$, but can only be understood in relation to the Father and his relationship to the Son, Jesus Christ. This Christological focus on creation he formulates as follows: "...creation is where light falls around the cross..." (Noordmans $1979: 245,263)$. Due to the fact that his view on creation is fundamentally informed by a Christological perspective, he focuses on the critical nature of God's act of creation ${ }^{19}$. He points out that when we confess our belief in God the Father, the Creator of heaven

16 De Knijff (1958:207-8), in agreement with Breek, criticises Noordmans for placing too great an emphasis on creation as division and not allowing for the Scriptural attestations where creation is viewed as formation. De Knijff (1970:84-92) proposes that the division of light and dark is not the same as the division between man and sin after the fall. Noordmans (1981:655) reacts to similar criticism from Prof. Van der Leeuw, by pointing out that one easily forgets how great a price was payed for the continuity of 24 hours in one day if one forgets that it is the Word that divided night and day.

17 In "Verzamelde Werken II", Noordmans (1979:245, 251, 255, 259, 263) uses the expression: "Scheppen is scheiden". It is difficult to translate into English, since "division" is too soft a term. Maybe "judgment" or "crisis" would suit the meaning better. Its meaning is best understood within the trinitarian relation to Christ's cross as set out in Noordmans' work. Noordmans (1981:681-689) explains his motivation for his view on creation as division in "Verzamelde Werken III" in his discussion of Barth's doctrine of creation.

18 De Knijff (1970:40-2) shows that Noordmans uses the term "creation" in three different ways; namely, creation in the ordinary (naive) sense, creation as qualification (only knowable through Christ) and creation as recreation by the Spirit. De Knijff attempts to show that Noordmans sees this first creation as incomprehensible except through the eyes of faith by way of an extrapolation from the salvation historical activities of Christ in history (second use). The third use is then an application of the qualification of Christ by the Spirit through the process of recreation. De Knijff tries to explain the three uses of the term without taking into account the trinitarian focus of Noordmans. From a trinitarian perspective, where the relation between the Father and the Son and the Spirit is taken into account, creation cannot be viewed in a static scientific manner, but its critical character becomes evident through the eyes of faith, “...wanneer wij de schepping niet trinitarisch benaderen, kunnen wij er in de toespraak niets mee aanvangen...” (Noordmans 1979:245).

19 “schepping is een kritisch begrip” (Noordmans 1979:245) 
and earth in the Apostle's Creed, we must be aware not to think of this confession as nature revealing a more evident truth than the confession about Christ and the Spirit. The Holy Spirit must convince us that the Creator is the Father of Jesus Christ, because Providence $^{20}$ might take care of the lilies of the field, but why does mankind still grow hungry? (Noordmans 1979:207-208).

Like Marcion and the Gnostics who have many followers in modern rationalistic theology, the tension between the Creator and Christ $^{21}$ is so intense that many people cannot find the connection. Noordmans (1979:252) sees this unbridgeable gap as evidence of the fact that creation is just as much a question of revelation and belief as the fact that Jesus is the Christ.

For Noordmans (1979:245-247), placing creation in relation to the Word (Gn 1 and Jn 1, Heb 11:3) and thereby the Father (Creator) in relation to the Son, precludes an abstract scientific view of nature. Creation is placed within the confessional sphere ${ }^{22}$ where our sinful nature precedes any view of nature that we might have. He proposes that Scripture speaks of the good creation only as a measure of the Fall, which occurs almost immediately after the creation of Adam and Eve and is perpetuated throughout the Old Testament. In the New Testament it is evident in the rich young man, the sores on Lazarus, the possessed ones, the tax collector and the prostitutes that surround Jesus.

The devastation of sin reaches as far as creation (Noordmans 1979:254). Therefore there is no point of contact between God and mankind in creation. Like Barth, Noordmans looks at God as well as at man from Scripture, and therefore does not find any point of

20 Noordmans (1979:250) fundamentally criticises the idea of Providence, since the idea of Providence easily ties God too closely to nature.

21 This fact makes Augustine's view of the Spirit as the bond of love between the Father and the Son (Jonker 1981:21) a very poignant one.

22 This is evident in the fact that Noordmans (1980:333) shows that the six thousand years of which Scriptures speak is enough to show God's judgment and salvation. Scriptures does not need more time to show us our sin and need of Christ. The Kingdom has come close, why would one need to go to the beginning of time to know that man is dead in his sin and in need of live-giving Spirit? (Noordmans 1979:246). 
contact between the two. There is "...no connection with the natural religious conscience in mankind, for example in the concept of God and God's existence or about God as Creator, to deduce the 'specifically Christian' contents of faith concerning Jesus Christ and the Spirit, concerning reconciliation and salvation as particular forms of general religiousness...”23 (Blei 1981:214).

To view creation as formation rather than division is to allow concepts that are untouched by sin and take on independent life, like personality, existence, substance, law, virtue, Mother Earth, blood, community, nation etcetera. (Noordmans 1979:256-259). Creation is in a sense only a reality in the sphere of belief in Scripture, not a biological entity. That is why Miskotte (1960:23) calls Noordmans's view of creation forensic, "der Reflex einer Reihe van Urteilen Gottes” ${ }^{24}$. Breek (1958:205) says that Noordmans consistently works out the declaratory, justificatory elements of Scriptures and the Reformation in his view of creation.

For Noordmans (1979:252-259), creation as a dividing judgment of God in the cross of Christ, does not allow for any unbroken form. Thus, the point of contact between God and mankind is not situated in creation, but resides in the promise of the gospel, in God Himself, where Jesus Christ followed us in the Fall and placed Himself under the judgment. God's judgment drives the Fall forward towards the cross, where his Son stands in the middle of the judgment, the cross in the middle of creation ${ }^{25}$.

Blei (1981:216-7) compares Noordmans's view of creation as division to Barth's view that "creation is the external ground of the

23 “...géén aanknopen bij natuurlijk-religieuze beseffen in de mens, bijvoorbeeld over het Godsbegrip en het Godsbestaan, of over God als Schepper om vervolgens dan de 'specifiek-christelijke' geloofsinhouden, inzake Jezus Christus en de Geest, inzake verzoening en verlossing, te kunnen voorstellen als 'verbijzondering' van dit algemeen-religieuze...” (Blei 1981:214).

24 Miskotte wrote this in the "Einführung" of the German translation ("Das Evangelium des Geistes”) of Noordmans’ Gestalte en Geest.

25 Where the cross of Christ is usually seen as something that reduces our view of the world and humanity, Noordmans proposes that this seemingly narrow perspective actually broadens our view to include sinners (the broadest possible perspective on man). 
covenant”, but proposes that Noordmans more radically disallows any form of natural theology. Reitsma (1997:62) concurs that both for Barth and Noordmans creation is a critical theological concept, but that Noordmans allows for less continuity between creation and the world than Barth. Noordmans (1981:685-6) himself criticises Barth for not staying close enough to revelation in his view of creation when he moves from the two-natures of Christ ${ }^{26}$ to the creation, rather than from the work of $\mathrm{Christ}^{27}$ to creation and in so doing breaks the trinitarian bond. "Because he [Barth] is concerned with creation, he does not discuss sin and grace, which is the central focus of Scriptures, but other things..." ${ }_{28}$.

Noordmans (1979:496) further sees a crucial mistake in the Church Dogmatics in the fact that Barth still treats creation as formation ${ }^{29}$ when he draws an analogy between the being of mankind and God in the human husband-wife relationship ${ }^{30}$. Noordmans thus sees relationality ${ }^{31}$ as an analogy between God and man as one of Barth's severest mistakes ${ }^{32}$.

26 Barth places great emphasis on the relation between God and man in the person of Christ (Noordmans 1981:686).

27 He works out this idea further by saying that one knows Christ better from his work than from his nature, form or figure (Noordmans 1979:486).

28 'Omdat het over 'scheppen' gaat, wil hij [Barth JT] het niet hebben over zonde en genade, waar het in het centrum van het Evangelie toch om gaat, maar over andere dingen...”

29 Breek (1958:207-208) proposes that creation as form "laat zich niet verloochenen" and that despite Noordmans's criticism of Barth (and Augustine), he is not able to prevent the element of formation in creation in his pneumatology.

30 Barth (1958:285f) discusses this analogy in his Church Dogmatics III,2. Note his apologetic discussion of anthropology just prior to this (1958:277-9) regarding the good insights of worldly wisdom which often relates closely to Christian anthropology (especially the reference to Buber whose insights about the I-Thou relationality greatly influenced Barth's discussion). Note the unacceptibility of sin for explaining a shared humanity (1958:279).

31 Berkouwer (1957:100) interprets Barth more positively when he says that Barth would probably not be satisfied to speak of man's relation to God as some essential characteristic of mankind, without qualifying this relation immediately as one of grace. It remains a question if this positive statement could be applied to Barth's creational explanation of relationality: “This I-Thou 
Noordmans's critical trinitarian view of creation, correlates with his view of the incarnation. Just as creation is a critical concept and a confession of faith, so is the incarnation.

\section{INCARNATION AS CROSS}

Noordmans (1979:278) proposes that the incarnation must be seen as the trinitarian work of the Spirit and not as an extension of creation. In so doing, he fundamentally criticises those approaches that view the incarnation in creational terms. A critical division concerns not only creation and its presupposition of the judgment of the cross, but also the incarnation, in order to maintain the trinitarian perspective. Christ's incarnation is not prolonged "naturally" in the church nor his humanity in mankind ${ }^{33}$.

relationship in its distinctive factuality and necessity is thus characteristic of his whole being, controlling it and giving it its character as fellow-humanity. We also saw that in this fellow-humanity, and at the very point where it emerges unequivocally as a natural fact of creation, i.e., in the co-existence of man and woman..." (III,2:317) and "Yet the fact remains - and this is something which belongs to us as the creatures of God, which is part of our human essence, which can rightly be called a human and even the typically human attribute that we are covenant partners by nature and in our mutual dealings, the man with the fellow-man, the I with the Thou, the man with the woman. This is something which is our own, and is inviolable and indestructible. This constitutes the unbroken continuity of human existence. We are created as mutual partners. And this leaves open the further possibility that we are created to be the partners of God. The latter statement speaks of the free grace of God in relation to man created with a specific nature. But it does undoubtedly speak of this human nature as such" (III,2:320).

32 Prenter shares this criticism of Barth, saying that his anological thinking, in which the humanity of Christ is an Abbild of the trinitarian being of God, while common humanity is in turn an Abbild of Christ's humanity, as well as his analogia relationis (as the natural relationality of man and woman) misses the soteriological distinction between sin and grace and falls within the Roman Catholic scheme of nature and grace. Van Niftrik (1951:510) is of the opinion that Prenter does not see Barth's analogical thinking within the soteriological framework where all humanity is imputed through the salvation in Christ.

33 This makes the multiple incarnations or incarnation as metaphor proposed by Hick in The metaphor of God Incarnate impossible. Hick (1993:98) sees the metaphorical value of the incarnation as something, which allows for the different incarnations of the ideal human life in the different 
Noordmans (1979:499) almost surgically removes all forms of continuation of incarnation with regards to holy persons ${ }^{34}$, the institution of the church, the Lord's Supper, the liturgy, and culture. Hasselaar (1958:10) emphasises this point with regard to Noordmans's view of anthropology when he says that "...the incarnation is most probably also not a suitable motive to serve as Christological foundation for the anthropology (anti-Barth)...” ${ }_{35}$.

Berkouwer (1957:94-5) sees Karl Barth as a proponent of a Christological anthropology ${ }^{36}$. For him the humanity of Christ is the true humanity. Human kind does not have access to its nature except through Christ. He who was without sin was the true man. Despite mankind's sin, it cannot destroy its true nature, which is being with God in Christ $^{37}$. Van de Beek (1980:59) criticises Barth for not taking mankind in his relation to God seriously enough, because he sees exclusively man as having personhood in an anhypostatic unity with Christ. Berkouwer (1979:98) criticises Barth for not staying close to the attestation of Scriptures, because Barth does not see Christ as taking part in our nature, but rather that we partake in Christ's nature (in whom we have our true nature).

Noordmans (1981:516-525) distinguishes between a Lutheran and a Reformed type of Christology. For Barth, as a proponent of the Lutheran type, Christ is a place where divine and human natures (spirit and flesh) meet momentarily, which presupposes an

religious figures in history. This is Hick's attempt to circumvent the logical problems with the doctrine of the two natures and the uniqueness of Christ.

34 This is seen in relation to the nature, above-nature of the Roman Catholic scheme (Noordmans 1979:474).

35 "...stellig is de Incarnatie ook geen geschikt motief om als christologische grondslag te dienen voor de antropologie (anti-K.Barth)...” (Hasselaar 1958:10).

36 See Church Dogmatics III,2 p. 71f.

37 Creation is thus aligned for Barth with redemption. That is also why his anthropology is closely related to his supralapsarian view of creation where the covenant is the internal ground of creation. 
impersonal anthropology. The Reformed type sees Christ as a person in his own right in whom both natures are united ${ }^{38}$.

Kohlbrugge, another representative of the Lutheran type, argues that the Word becoming flesh $^{39}$ does not compliment humanity. Rather, becoming flesh implies becoming sin and a curse (Gl 3:3) for our sake (Noordmans 1979:524). The impersonal anthropology of this type sees the communion with God through the flesh as the immediate meeting of opposite natures. Christ cannot be drawn too deeply into the flesh (Luther 1966:68) and that is said to his honour. The tension between Spirit and flesh must be stretched to its maximum (Noordmans 1981:518). The deeper he goes into the flesh the more completely Christ identifies with sinful humanity and the greater is the salvation. Christ became flesh to destroy it.

38 Van de Beek (1998:17-24) distinguishes between two main branches in Christology. In the Alexandrian Christology, Christ took on humanity in the flesh and not a human person as in the Antiochan Christology. For the Alexandrian school, the human nature of Jesus Christ does not have an independent personality (is anhupostatos), but the person of the Logos bears the humanity of Jesus. This view guards against seeing Christ as taking on only one person, because then He could only try to save Himself, not all of humanity. He was made sinful and yet did not sin, otherwise he could not bear the sin of the world. How other individuals partake in his humanity is anwered in terms of Pneumatology (Van de Beek 1997:12-18). Due to certain philosophical considerations the Antiochan Christology wanted to make a sharp distinction between the divine and human natures of Christ (Van de Beek 1998:17-19). The personal anthropology with its adoptianist tendencies in the Reformed type does relate to the Antiochan approach, and the sharp distinction between the human and divine natures of the Alexandrian type bears some resemblance to the Lutheran type. McKim (1988:37) appropriately calls the two dominant approaches to Christology the Word-flesh model and the Wordhuman model.

39 Van de Beek $(1998: 43-45,51)$ emphasises the importance of holding on to the paradox of the two natures of Christ, because what He did not take on Himself, humanity is not saved of. If He were not God he could not save humanity. He proposes that if He is drawn too deep into our sin (to sin himself) He must bear his own sin and if He is too far removed from our sin He cannot bear it for us. 
The Reformed type sees the communion with God through Jesus' humanity as it is mediated by the Spirit ${ }^{40}$. The two natures are united in Christ's person and there is a growing awareness in his human nature of his divine nature. For the Reformed type, therefore, the meeting of two natures is extended throughout the whole life of the believer (Noordmans 1981:521).

Taking out the absolute from the person's life of faith and placing it in God's decrees (in the predestination), is the basis of the Reformed confession of the perseverantia sanctorum. There is thus an ethical ${ }^{41}$ mediation between God and mankind, but this is not through a natural personality, but through a growing awareness of a person's humanity in Christ as mediated by the Spirit.

Noordmans (1981:525) points out that this ethical view has its boundaries, "We must know this to our comfort. When Calvin has extended the ethical element in us into the dark foundations and background of creation ad absurdum, then it is a relief to hear from Luther, that God lives beyond our boundaries and sees our misery from there ${ }^{42}$ ”.

Noordmans therefore seems to allow for the importance of both the Lutheran and the Reformed perspectives. The Lutheran type

40 Pneumatology plays a great role in the Antiochan (Reformed) Christology. The more impersonal meeting of two natures in the Alexandrian model (Lutheran type) allows less room for a doctrine of the Spirit. The impersonal anthropology of the Alexandrian model (Word-flesh) carries a more critical character, which does not leave much room for an independent anthropology. Anthropological reduction does take place, but usually in relation to the humanity of Christ in Christology. The Antiochan model (Word-human) has much more potential for anthropological reduction, but this usually takes place within the Pneumatology.

41 This term is used within the framework of "ethical" theology, a tradition in which Noordmans stands. "Ethical" does not refer to behaviour or morality, but to existential involvement in the truth of God in opposition to "rational" or objectivised knowledge (Veenhof 1968:91).

42 "Wij hebben dit bovenal te weten tot onze troost. Wanneer Calvijn in de donkere grond en achtergrond der schepping onze ethische bepaaldheid ad absurdum gevoerd heeft, dan is het een verlossing van Luther te horen dat God buiten die grenzen woont en vandaar onze ellende ziet” (Noordmans 1981:525). 
allows for a more clear-cut, critical distinction between God and man with its anthropology mainly located in Christology, where the contact between God and man occurs by way of intermittent meeting of natures in preaching. The Reformed type sees the life of faith as something, which does have greater continuity, although this is not the continuity of an impersonal contact between natures, but of faith. Their anthropology is therefore mainly located in Pneumatology. This view of the mediation between the human nature of Christ and our human nature may tempt us to forget that there is no direct unmediated contact between God and humanity.

Noordmans (1979:358, 444) warns that one must be aware not to make an idol of Christ. He is not the ideal human, nor the hero nor the philanthropist ${ }^{43}$. He is the image of God (Col 1:15), but this is a truth of faith in the Father, Son and Spirit and does not find a point of contact in the humanity of the earthly Jesus ${ }^{44}$. The presence of God in Jesus' humanity remains hidden ${ }^{45}$ (Noordmans 1979:274). That is why his "image" must be broken by the Spirit and given to the believer like the bread and blood of the Lord's Supper ${ }^{46}$. One must remember that Christ had no form that we should desire him (Is 53:2); (Noordmans 1979:486). Noordmans (1988:218-221) criticises

43 Noordmans $(1980: 358,9)$ shows that the foolishness of the God (1 Cor 1:25), who presents Zacchaeus as a model financier and the woman with the expensive ointment as an example to society. "Daarom moet men in zijn vleeswording, ook geen wijsheid dezer wereld zoeken. Hij neemt daarin geen model-mens aan, die voortaan als voorbeeld in de kerk zou kunnen staan en in welke vereniging ook de cultuur dezer wereld haar verborgen wortels zou hebben".

44 Noordmans proposes this in his discussion of Sunday 7 of the Heidelberg Catechism where faith is related to the trinitarian confession in the Apostles Creed and not to human similarities with Christ.

45 "Een aanschouwelijkheid voor vlees en bloed mogen wij daarom aan de Zoon in die prediking niet trachten te geven...Elke begeerte om daar een genie of held te vinden is heidens. Ook mag men Jezus niet tekenen als een sociaal hervormer; of als de profeet van een natuurlijke vroomheid, wiens ziel 'van nature christinne' was, of als brenger van een gezindheidsethiek, een zedelijkheid van de binnenkamer des harten...” (Noordmans 1979:274).

46 The whole "life of Jesus" theological movement tends to look for Jesus behind the Gospel and this whole endeavour would be judged by Noordmans as knowledge of Christ according to the flesh (2 Cor 5:16) and thus idolatry. 
Korff's Christology for trying to portray the unity of the two natures of Christ too visually, while showing how Calvin portrayed the broken communion with Christ through the Spirit ${ }^{47}$. Literary attempts to portray Jesus "visually" pleasing, are usually not convincing. There must be Spiritual mediation in any portrayal of Christ, which Noordmans (1979:241) finds more convincingly done in The Idiot by Dostoyevski ${ }^{48}$.

Noordmans (1979:500-501) points out that the human and divine natures of Christ did not mix into a third nature for human participation. His “taking on" humanity does not enable us to partake in a different nature or the betterment of our own, but expresses how He took on sin, death and hell in our place. His taking on of our humanity does not effect ${ }^{49}$ or point to something divine in our nature $^{50}$, but illustrates his grace to sinners. Mankind, therefore, does

47 Noordmans (1988:220) says that Korff's (1942:68-70) statement “Het geloof kan zich slechts daarom op Jezus Christus richten, omdat het in Hem God ziet”, together with the consequent discussion on the way the historical reality of Christ and faithful sight work together sounds strange to Reformed ears, since it focusses faith too much on a direct historical entity. Making a visual representation of Christ detracts from the Spirit's work of sharing Christ with us through faith.

48 This distinction can be illustrated in the two films "The Passion of the Christ" by Mel Gibson and the film "The man without a face" based on the book by Isabell Holland in which Mel Gibson plays the main character. The first is a repetition of the facts of salvation, the second shows the Christlike suffering of a mutilated man falsely accused.

49 There is no theosis or deificatio where the Spirit deifies human nature by way of participation in the divinised human nature of Christ (Jonker 1981:30). Van Ruler (1969:178) also emphasises the fact that Christ was unique and that mankind does not participate in the divine in the way that Christ's divine and human nature meet in an anhypostatic or enhypostatic manner, but by way of the Spririt where man stands over against the Spirit, "De mens... die - voor Gods aangezicht...- zijn mannetjie staat... tegenover God".

50 Noordmans (1980:242) says heathenism is to try to be lifted above one's nature, while the gospel teaches us that God works the other way around. Not uplifting our nature to above-nature (in the Roman Catholic scheme), but by the Son who takes on our nature (human) and the devastating of his own (godly) nature. Heathenism would also see that God becoming flesh in Christ's humiliation would turn into man becoming God in the resurrection (Noordmans 1979:284). Communion with Christ is only possible when He meets us where 
not partake in his becoming human, but thankfully believe in the fact that He did.

Noordmans (1980:243-245) says that Christ did not merely take on Adam's humanity ${ }^{51}$ to compliment ${ }^{52}$ us or to place us above the other creatures ${ }^{53}$, but was made sin (2 Cor 5:21), became flesh and in doing so humiliated Himself even deeper than what we would consider human, finally even unto death (Phil. 2) ${ }^{54}$. Accordingly one cannot deduce references in 2 Corinthians 5 from the account of Luke 2. In his meditation on Saul (Verworpen), he shows how Christ did not choose the beauty and the concomitant tragedy, which leads to the demonic effusion of humanity in the person of Saul, but the humiliation of the death on the cross ${ }^{55}$. The incarnation was not done in honour of some ideal humanity, but for the salvation of real humanity.

Noordmans (1980:234) also points to the fact that the promises of God came true through the fall of King David, because the son of David was born from the sinful marriage with Bathsheba, not Michal

we have fled from God, not when we try to climb up the nature of the eternal Son (Noordmans 1979:490).

51 "Niet een geboorte-zonder-meer, doch de vleeswording, niet de dood op het eind van een leven, maar het verzoenend sterven aan het kruis" (Noordmans 1980:333).

52 Christ did not come to honour humanity, but to save it (Noordmans 1979:506).

53 "Hij is mens geworden, omdat wij de ellendigsten van alle schepselen zijn” (Noordmans 1980:244).

54 Just like his birth is followed by his shame on the cross in the Apostolic Confession so his kenosis is followed by his humiliating suffering (Phlp 2:7, 8)

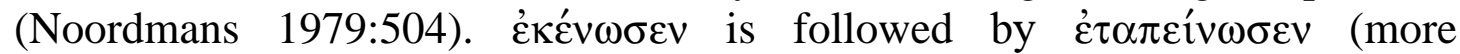
humiliate than humble).

55 "Zijn gedaante zou een uitstulping van het humane vertoond hebben en God had ook Hem moeten verwerpen. Maar Hij koos een menswording, bestaande in ontlediging, en als mens koos Hij de de vernedering tot de dood des kruises. En nu kon God Hem verhogen (Phlp 2:7vv). Daarom moet men eens ophouden met te zeggen en te schrijven, dat Christus door zijn incarnatie de mensheid heeft willen eren, zoals een aanzienlijke gast zijn intrek neemt in het beste hotel van de stad...Dat betekent een demonisering van ons christelijke geloof” (Noordmans 1980:213). 
(who was childless). He says that we find it hard to accept that despite the fact that we are created in God's image there is no correlation between God and mankind, which mankind can get in its grip. Mankind "forgets that we know little or nothing of God except that He involves himself with sin. Also of the Son of God, the son of David, Jesus, who is called 'the image of the invisible God' (Col $1: 15)$, we really know nothing more ${ }^{56 ”}$. One could argue that this is an incredible reduction of anthropology, but Noordmans proposes that seeing the trinity and humanity in light of sin and grace is at the same time the wonderful simplification and generalisation brought about by the Reformation.

Noordmans (1979:477) emphasises the once-off historicity of Christ by pointing out that we cannot take part in his human nature nor his divine nature ${ }^{57}$. We are not sons by nature and his unmixed natures remain something which we cannot share. It is neither possible to imitate Christ's humiliation from the divine likeness to god-forsakenness, nor his substitutive resurrection and his sitting on the right hand of God. The judgment of God distinguishes between these works of Christ and our work. We partake in it not by sharing in these works, but by imputation. Christ's communion with the crowd that surrounded him in Scriptures was also an unrepeatable event, which cannot be continued by any church, pope, sacrament or holy people (Noordmans 1980:261). Noordmans (1986:417) interprets the Roman Catholic view on the continuation of the incarnation as their taking possession of the Spirit. He refers to Dostoyevski's The Great Inquisitor ${ }^{58}$ to illustrate how the Church has succeeded Christ and has no more need for Him. The incarnation was a once-off event that can only be perpetuated in the work of the

56 "Hij [mensdom] vergeet daarbij, dat wij van God weinig of niets weten dan dit, dat Hij zich met de zonde bemoeit. Ook van de Zoon van God, de Zone Davids, Jezus, die genoemd wordt "het beeld van de onzichtbare God" (Col 1:15), weten wij eigenlijk niets anders.”

57 Noordmans (1979:488) distinguishes between Christ's Sonship (and divinity) from eternity and the way we are taken on as children of God.

58 This story comes from the book The Brothers Karamozov. It tells the story of Jesus coming back to earth and how the Cardinal rebukes him for coming to disturb the church. 
Holy Spirit (Noordmans 1979:279). Christ has no successor in the Church other than the Holy Spirit.

If one translates Christ's coming into the flesh as being continued in our humanity without allowing the Spirit to take from Christ and imparting it to us, one would exchange the last Adam, the live-giving Spirit, for the first Adam, who is only a living soul (1 Cor 15:45) and by doing so run the risk of calling on Jesus, but sinning against the Holy Spirit ${ }^{59}$ (Noordmans 1980:360).

The preceding discussion on creation as division and the incarnation as cross is succinctly summed up when Noordmans (1980:244) says, “...Christ is obscure in humanity, just like God cannot be found in nature..." ${ }^{60}$.

Noordmans consistently draws trinitarian boundaries between the Father and creation, Christ and humanity. He continues this trinitarian criticism by drawing clear boundaries between the Holy Spirit and the human spirit.

\section{THE SPIRIT ON ALL FLESH}

In his work Herschepping, Noordmans (1979:298) points out that it is very difficult to hold on to the unity between the Father and Christ, while it is difficult to keep the distinction between Christ and the Spirit, and the Spirit and our human spirit. It appears as if the Holy Father is far from sinners, Jesus Christ having come into sin is in a sense beneath us, while the Spirit is closer to us than both, and that is why the Spirit can easily be confused with our own spirit.

59 "Wij leven dus onder de bedéling des Heiligen Geestes in een voortdurend en waarlijk dodelijk gevaar...Het gevaar van, met een beroep op Jezus, te zondigen tegen de Heilige Geest en diens vertolking niet te aanvaarden” (Noordmans 1980:360-1). Noordmans (1980:378-9) describes this sinful fascination with the person of Jesus Christ as knowledge of Him according to the flesh and not according to the Spirit. He contrasts the disciples' fleshly knowledge of Him with Paul's spiritual knowledge of Jesus Christ through the Spirit. Against all quasi-liberal searches for the historical Jesus as well as quasi-philosophical orthodox (respectively, fundamentalist) certainty, Noordmans (1978:189-203) confesses that Christ Jesus neither has historical foundation nor metaphysical ground.

60 "Christus is obscuur in de humaniteit, zoals God niet te vinden is in de natuur..." 
In Gestalte en Geest, Noordmans (1980:360) illustrates that Jesus Christ, regarding his person and his work cannot be perpetuated in any way, since the Spirit, as the third historical procession of God is evident in Scriptures. Christ Himself said that He would send the other Comforter who will take from Him and give to the disciples. This is a new work of the Spirit, which can only be apprehended spiritually.

Just as there is no continuation of the incarnation, so one could say that Noordmans's view on the Spirit does not allow for any continuation of the work of the Spirit in mankind. The Spirit is a person who must not be confused with the spirit of the congregation (Noordmans 1980:352), the Gemeingeist (Noordmans 1979:172) or the human person (Noordmans 1979:537).

Badcock (1997:40, 54) points out how the Christological controversies of the early church were perpetuated in the differences in Pneumatology. Following Berkhof he distinguishes between the Logos Christology and the Spirit Christology ${ }^{61}$. In the Logos Christology the divinity of the Logos is of central importance and in the Spirit Christology, with its emphasis on the baptism of Christ by the Spirit, the Spirit's divinity takes precedence ${ }^{62}$. The soteriological

61 Schoonenberg extensively discusses this distinction and interestingly points out that the Alexandrians preferred the Logos Christology over against the Antiochans who had a predisposition for the Spirit Christology, which in turn was reflected in their view of salvation. In Logos Christology salvation comes through the incarnation of the Son, in Spirit Christology the salvation comes through the new Adam. That is why Schoonenberg $(1991: 53,4)$ proposes that one could use the terms "incarnation" and "inspiration" to define these Christologies respectively. Noordmans's criticism of the incarnation and his emphasis on the person of the Spirit show his sensitivity for the Spirit Christology, while his emphasis on the unique work of the person of Christ in our salvation prevents the mere inspiration of mankind by the Spirit as the way of salvation. This illustrates why the trinitarian view on anthropology is so crucial.

62 The same anthropological reduction, which is possible from a Christological perspective, can take place within a Pneumatological one. Either the divinity of Christ is emphasised to the anthropological reduction of the Spirit to the human spirit or the divinity of the Spirit is emphasised to the anthropological reduction of Jesus to an ideal human, where the Spirit is identified with the Logos. Either of these reductions results in the development 
motivation for the confession of the divinity of Christ in the early church was also the motivation behind the confession of the divinity of the Spirit ${ }^{63}$.

Berkhof says that, in Scriptures, the Spirit (the other comforter) has a relative independence with regard to Christ, but is also sometimes identified with the risen Christ ${ }^{64}$. To some extent Berkhof (1981:142) follows the more independent view of the Spirit ${ }^{65}$. He praises Noordmans's Pneumatology for not being so one-sidedly Christological (like Barth) or traditional, due to the fact that he

of an independent anthropology. In the Antiochan Christology, which runs the risk of giving the humanity of Christ a certain independence, Christ is, according to his human nature, the morally ideal human (the real man), to be imitated (Van de Beek 1998:76).

63 Badcock (1997:264-268) himself, however, in an attempt to point out the necessity of the interpenetration of Christology and Pneumatology confuses the work of the Spirit with general anthropological spirituality seeing Jesus as an example of our common humanity. Welker (1994:314) with his view on the Spirit as "the pluriform unity of perspectives on Jesus Christ" which is "a unity in which we help to constitute" and as a "public person", moves dangerously close to confusing the Spirit with the collective spirit in the church community.

64 Berkhof (1973:341-9) proposes that this second perspective, for which he seems to have an affinity, does not fit well with a trinitarian view on the personhood of Christ and the Spirit. The Spirit is God-as-person or God-inrelation uniting God and mankind (as represented in Christ) and does seem to be more of a power than a person. Berkhof also proposes that a pneumachristology (Spirit becoming flesh) in the early church was quickly replaced by a logos-christology and that it was wrongfully seen as the start of adoptianism. These are the dangers faced by not honouring both the Spirit and Christ as persons in the trinity.

65 Berkhof (1964:24) lists this independent work as conversion, sanctification, miracles, sending and mission. König (1970:374), in contrast to Berkhof, maintains that there is no originality in the work of the Spirit and shows how the things, which Berkhof lists under the original work of the Spirit are also directly applied to Jesus like conversion, sanctification, miracles, sending for mission etc. Berkhof (1973:343) himself points out that he is not consistent with regard to his view on the independence of the Spirit. 
makes room for the freedom of the Spirit in the interpretation of Christ $^{66}$.

Van Ruler (1947:200) on the other hand emphasises the fact that there is no question of identification between the Holy Spirit and Jesus Christ and consistently maintains the relative independence of the Spirit with regard to Christ. He points out the necessity of allowing for the difference in the Christological and the Pneumatological perspectives within theology. Over against the notion of the prolongation of the incarnation, the Word becoming Flesh and the outpouring of the Spirit were unique events. God and mankind stand over against each other as Creator and creature. Man partakes of God not in a Christological sense by sharing in the humanity of Christ, but in a Pneumatological sense whereby the triune God lives in man through the Spirit, without the creature becoming God. For Van Ruler (1969:181-190), the intimate relation between the Spirit and all of creation allows for the concept of mixing, which is not possible within the Christological perspective, with its narrower aim at the substitutive suffering for mankind's sin.

Van Ruler (1999:84-85) presupposes a kind of of creaturely existence, which is not touched by sin and where mankind does have some independence over against God. Van Pelt criticises Van Ruler by stating that he presupposes some sort of neutral part in creation where sin did not penetrate and by doing so underestimates the pervasiveness of sin as attested to in Scriptures. Noordmans's view on creation as division would not allow for any such neutral part of creation.

Van Ruler proposes that the Spirit's relation to humans is not the same as his relation to Jesus Christ ${ }^{67}$. Bohren (1980:75) concurs with him on this point by showing that the difference between Christ and humanity lies in the fact that, "Das Wort ward Fleisch, Gott wurde Mensch; aber der Heilige Geist wurde über das Fleisch

66 Berkhof (1964:92-103; 1981:152,153) sees the whole Pentecostal movement as having a perspective that is not properly reflected within theology.

67 Berkhof (1973:343) criticises Van Ruler that his distinction between the assumptio of Christ and the adoptio of humans by the Spirit implies that Christ was not truly human. 
ausgegossen”. Noordmans (1980:351) himself points out that one must guard against seeing the confession of the Spirit as the work of God in us, and that of Christ as the work of God on behalf of us. Easter loses its redemptive meaning if one does not understand that the Jesus came into our existence and the Spirit came over us $^{68}$.

For Noordmans Christ became sin and in a sense meets us from the side of sin, through the interpretative work of the Spirit, rather than from the side of created nature or morality. The Spirit's work with regard to Jesus Christ is to draw him into our sin, while his work with regard to us is to console sinners with the fruit of Christ's life-long sacrificial suffering.

Like Van Ruler, but within a different framework, Noordmans points out the necessity of the relative independent work of the Spirit $^{69}$. When the latter is not taken seriously the human spirit tends to objectivise the facts of salvation like the orthodoxy, historicise it like the liberalists or spiritualise it like the spiritualists $^{70}$. Consequently, the work of the Spirit is confused with human concepts of God, hermeneutical aptitude, natural abilities, spiritual proficiency and moral sensitivities, in short - with the human spirit ${ }^{71}$.

68 In his meditation, De Overmacht des Geestes, Noordmans (1980:351) states: “...dat wij bij de belijdenis van de Heilige Geest niet dadelijk en niet altijd moeten denken aan Gods werk in ons, terwijl het ambt van Jezus dan zou zijn een werk aan ons. Men zou het zelfs kunnen omkeren en zeggen, dat Jezus in ons bestaan gekomen is en dat de Heilige Geest over ons komt”.

69 In the context in which Van Ruler (1947:200) speaks on the topic it seems as if he was informed by Noordmans in this regard (he does not refer directly to him, but makes mention of his Pneumatology in close proximity).

70 Noordmans distinguishes himself from the orthodox, the liberal and the spiritualist by respecting the divinity of the Son and the Spirit completely, without anthropological reduction. The Spirit is the third historical procession of God and the independence of his work must be believed.

71 Van Pelt (1999:42), refering to Noordmans' Herschepping criticises pastoral theology for attempting to translate theology into psychology and find some sort of continuity of conscience between the old and the new man. This natural analogy presupposes something within in a person that must be developed ignoring the gap (of death) between the old and the new man, which can only be crossed by the Spirit. 
For Noordmans every element in salvation finds its place in faith ${ }^{72}$, which in turn rests in the trinitarian work of God that has the predestination as its great foundation. Noordmans (1979:306-317) sees no human quality or ability as the foundation in rebirth or conversion, for Christian life and holiness are critical terms. They are all judgments of the Spirit, which excludes any continuation with the human spirit or the incarnation isolated from the cross.

All historical and natural forms are broken down when the Spirit interprets the cross of Christ to us. Everything that is given an independent or detached position over against God's purpose of salvation comes under the judgment of the Spirit, even the work of Christ itself.

In his work Herschepping, Noordmans (1979:305) says the broadest description of the work of the Spirit can be called "Recreation". Like the creation of the Father this is a critical term, which does not refer to formation, but to a critical division. The judgment of God continues from creation through redemption unto recreation, "He is above creation with His judgment as Father; under the judgment, as the Son; in us with his judgment, as the Holy Spirit"'

\section{CONCLUSION}

The all-elusive point of contact between God and humanity, the space between the finger of God and the finger of Adam remains a moot point. Most attempts at an answer ends up by transgressing the boundaries set by God.

Noordmans emphasises the fact that creation itself is a critical concept that must be seen in relation to the cross. The incarnation does not lessen the distance between God and mankind, but shows the depth of sin and leads up to the judgment of the cross. There is no continuation of the work and person of Jesus Christ by means of the church, holy persons or liturgy. The Spirit has a relative independence in relation to the Son. He takes from Christ's work and

72 Berkouwer has extensively worked out this same perspective in his works "Geloof en Rechtvaardiging”, “Geloof en Heiliging” and "Geloof en Volharding”.

73 "Boven de schepping is Hij met zijn oordeel, als Vader; onder het oordeel, als de Zoon; binnen in ons met zijn oordeel, als de Heilige Geest”. 
through judgment imparts to sinners what Christ has done, excluding any attribute or ability in mankind. He is poured out over all flesh and should therefore not be confused with the spirit of mankind.

Not in creation, the incarnation or the spirit of man does one find the point of contact. Noordmans' reformed, trinitarian theology attempts to respect the distance between God and humanity following the revelation in Scriptures whereby mankind can only be understood in the light of the cross.

Interestingly enough, if one extends the tip of the finger of God and the tip of the finger of Adam the two lines form a cross.

When sin drives humans to get a grip on the Father through creation, on the Son through the incarnation and the Spirit through our individual or collective spirit, the judgment of the cross points to the devastation of our sinful inhumanity.

\section{Consulted literature}

Aldenhoven, H 1981. The question of the procession of the Holy Spirit and its connection with the life of the Church, in Vischer, L (ed), Spirit of God, Spirit of Christ, Geneva: World Council of Churches, 121-132..

Augustinus, A s a. De Trinitate. http://phil.flet.mita.keio.ac.jp/person/ nakagawa/texts.html\#august (accessed Jan. 2008).

Badcock, G D 1997. Light of Truth, Fire of Love. Grand Rapids: Eerdmans.

Barth, K 1958. Church Dogmatics: The Doctrine of Creation, III/2. Edinburgh: T\&T Clark.

Berkhof, H 1964. De leer van de Heilige Geest. Nijkerk: Callenbach.

-, 1973. Christelijk Geloof. Nijkerk: Callenbach.

-, 1981. Bruggen en Bruggenhoofden. Nijkerk: Callenbach.

Berkouwer, G C 1957. De Mens: Het Beeld Gods. Kampen: Kok.

Blei, K 1981. Noordmans over Barth, Kerk en Theologie, 32(3), 212-231.

Bohren, R 1980. Predigtlehre. München: Kaiser Verlag.

Boulgakov, S 1946. Le Paraclet (traduit par Constantin Andronikof). Paris: Aubier Editions Montaigne.

Breek, B 1958. Scheppen is scheiden: Enkele opmerkingen over de leer der schepping volgens Dr. O Noordmans, NTT 12(3), 189-208.

Browne, A 2007. Towards or Too Far, Expository Times, 118(7), 348.

Calvijn, J [1931]. Instituties. Delft: Naamloze Vennootschap Meinema.

De Knijff, H W 1985. Geest en Gestalte. Kampen: Kok.

Dixon, J W 1998. Toward a Trinitarian Anthropology, Anglican Theological Review, 8(2), 169-185. 
Grenz, S J 2001. The Social God and the Relational Self: Trinitarian Theology of the Imago Dei. Louisville: Westminster John Knox.

Gunton, C 1995. Relation and Relativity: The Trinity and the Created World, in: Schwöbel, C (ed), The Renaissance of trinitarian theology: reasons problems and tasks, Edinburgh: T\&T Clark, 92-112.

Guthrie, S C 1979. Pastoral counseling, Trinitarian theology, and Christian anthropology, Interpretation 33(2), 130-143.

Hasselaar, J M 1958. Dr. O. Noordmans: Hoofdmomenten van zijn theologie. 's-Gravenhage: Boekencentrum N.V.

Hick, J 1993. TheMyth of God Incarnate. Louisville: John Knox.

Jonker, W D 1981. Die Gees van Christus. Pretoria: NG Kerkboekhandel.

König, A 1970. Jesus Christus die Eschatos. Pretoria: NG Kerkboekhandel.

Korff, F W A 1942. Christologie. Nijkerk: Callenbach.

Luther, M D 1966. Martin Luthers Werke 10/I. Weimar: Hermann Böhlhaus Nachfolger.

McKim, D K 1988. Theological Turning Points. Atlanta: John Knox Press.

Merriel, D J 2005. Trinitarian Anthropology, in: Van Nieuwenhove, R \& Wawrykow, J (eds.), The Theology of Thomas Aquinas, Indiana: Notre Dame. 123-142.

Miskotte, K H 1960. Einführung, in Noordmans O. Das Evangelium des Geistes (aus dem Holländischen von $\mathrm{H}$ W de Knijff \& $\mathrm{H}$ Stoevesandt), Zurich: EVZ, 9-29.

Ndungane, N 1994. Human rights, in Villa-Vicencio, C \& De Gruchy, J (eds.), Doing ethics in context, Orbis Book: New York, 193-197.

Noordmans, O 1979. Verzamelde Werken, Deel 2, red deur J M Hasselaar (et al). Kampen: Kok.

-, 1980. Verzamelde Werken, Deel 8, red deur J M Hasselaar. Kampen: Kok.

-, 1981. Verzamelde Werken, Deel 3, red deur J M Hasselaar. Kampen: Kok.

-, 1986. Verzamelde Werken, Deel 6, red deur J M Hasselaar. Kampen: Kok.

-, 1988. Verzamelde Werken, Deel 4, red deur J M Hasselaar. Kampen: Kok.

Quellet 2007. Divine Likeness towards a Trinitarian Anthropology of the Family.

Reitsma, B J G 1997. Geest en schepping. Zoetermeer: Boekencentrum.

Schoonenberg, P 1991. De Geest, het Woord en de Zoon. Kampen: Kok.

Smail, T 2005. Like Father, like Son: The Trinity imaged in our Humanity. Grand Rapids: Eerdmans.

Smit, J R 1995. A. van der Kooi, Het heilige en de Heilige Geest bij Noordmans: Een schets van zijn pneumatologisch ontwerp, NTT 49, 170172. 
Van de Beek, A 1980. De menselijke persoon van Christus. Nijkerk: Callenbach.

-, 1987. De adem van God: de Heilige Geest in kerk en kosmos. Nijkerk: Callenbach.

-, 1997. Anhypostasia, in: Van Egmond, A \& Van Keulen, D (eds.), Studies in Reformed Theology, Nijkerk: Callenbach, 11-31.

-, 1998. Jezus Kurios: de Christologie als hart van de theologie. Kampen: Kok.

Van Niftrik, G C 1951. Zie, de mens! Nijkerk: Callenbach.

Van Pelt, J W 1999. Pastoraat in trinitarisch perspectief. Heerenveen: Uitgeverij Groen.

Van Ruler, A A 1947. De Vervulling van de Wet. Nijkerk: Callenbach.

-, 1969. Theologische Werk Deel I. Nijkerk: Callenbach.

-, 1973. Theologische Werk Deel VI. Nijkerk: Callenbach.

Veenhof, J 1968. Revelatie en Inspiratie. Amsterdam: Buijten \& Schipperheijn N.V.

Welker, M 1994. God the Spirit. Minneapolis: Fortress. 